\title{
Promoter methylation and expression of Raf kinase inhibitory protein in esophageal squamous cell carcinoma
}

\author{
HONG WEI, ZHIJUN LIU, HONGYAN SHE, BAOGUO LIU, JUNXIA GU, DONGMIN WEI, \\ XIANGYANG ZHANG, JIUFENG WANG, SHUJING QI and FUMIN PING
}

\begin{abstract}
Department of Pathology, The Affiliated Hospital of Hebei University of Engineering, Handan, Hebei 056000, P.R. China
\end{abstract}
Received July 9, 2015; Accepted November 23, 2016

DOI: $10.3892 / 01.2017 .5617$

\begin{abstract}
Raf kinase inhibitory protein (RKIP) regulates multiple cellular processes, and its downregulation is associated with distinct human cancers. In the present study, the status of RKIP promoter methylation, as well as its expression and clinical significance in esophageal squamous cell carcinoma (ESCC), were examined. The promoter methylation status in the 5'-CpG island of the RKIP gene and the expression level of the RKIP protein were examined using a modified methylation-specific polymerase chain reaction (MSP) method and immunohistochemical staining, respectively, in 77 ESCC samples and matched paratumor normal tissues. The incidence of RKIP promoter methylation was significantly higher in tumor samples (75.3\%) than in the matched normal tissues $(27.3 \%$; $\mathrm{P}<0.001)$. A higher incidence of promoter methylation was also detected in poorly differentiated cancers (93.5\%) compared with well-differentiated cancers $50.0 \%$; $\mathrm{P}<0.001)$, as well as in tumor samples with positive lymph node metastasis $(86.7 \%)$ compared with those with negative lymph node metastasis $(59.4 \%$; $\mathrm{P}<0.001)$. Consistent with the promoter methylation status, the expression level of RKIP was significantly reduced in cancer tissues (36.4\%) compared with matched normal tissues $(76.6 \%$; $\mathrm{P}<0.01)$, as well as in cancers with positive lymph node metastasis (24.4\%) compared with those with negative lymph node metastasis $(53.1 \%$; $\mathrm{P}=0.01)$. Promoter methylation-induced gene silencing significantly correlated with the down regulation of RKIP and the development of ESCC. The results of the present study suggested that the methylation status of the RKIP promoter, when combined with its expression level, may serve as a biomarker for predicting the biological behaviors of ESCC.
\end{abstract}

Correspondence to: Dr Fumin Ping, Department of Pathology, The Affiliated Hospital of Hebei University of Engineering, 80 Cong Tai Lu, Handan, Hebei 056000, P.R. China

E-mail:pfum@163.com

Key words: esophageal squamous cell carcinoma, Raf kinase inhibitory protein, DNA methylation, lymph node metastasis, tumor differentiation

\section{Introduction}

Esophageal cancer is among the most prevalent cancers in China, ranking sixth in terms of incidence and fourth in terms of mortality, according to the 2011 Annual Report on the Status of Cancer in China (1). The highest morbidity rate of esophageal cancer in China reached 130 per 100,000 people in 2003 (2). Esophageal cancer can be further divided into two main pathological subtypes: Esophageal squamous cell carcinoma (ESCC) and esophageal adenocarcinoma (EAC), with the former being the predominant type and accounting for $\sim 90 \%$ of esophageal cancer cases worldwide (3). Even though there have been significant advances in therapeutic approaches for ESCC, the prognosis of ESCC remains poor (the 5-year survival rate is $<10 \%$ ) (4). Therefore, it is essential to explore the pathogenesis of ESCC and to identify novel biomarkers for risk assessment, early detection and prognosis prediction.

Many genetic and epigenetic alterations have been implicated in the pathogenesis of ESCC. Among these alterations, DNA methylation-induced gene silencing of tumor suppressor genes plays significant roles in ESCC initiation, progression and metastasis; thus serving as important ESCC biomarkers (5). Although expression analysis alone is frequently used as the main approach to identify cancer biomarkers, Cheng et al recently proposed that integrating expression and epigenetic alteration analyses would provide a higher likelihood of identifying ESCC biomarkers (6).

Raf kinase inhibitory protein (RKIP) is a highly conserved, ubiquitously expressed and small cytoplasmic protein with various biological and pathological activities (7). RKIP inhibits Raf-1-mediated phosphorylation and activation of mitogen-activated protein kinase (MAPK) kinase (MEK)-1, as well as the subsequent MAPK and extracellular signal-regulated kinase activities (8). RKIP also negatively regulates nuclear factor (NF)- $\mathrm{\kappa B}$ signaling and the signaling downstream of $\mathrm{G}$ protein-coupled receptor kinase $(9,10)$. During cancer development, RKIP is characterized as a tumor suppressor gene because of its maintenance of chromosome stability, inhibition of cellular proliferation, promotion of cell differentiation and dynamic balancing of oncogene activities (11). Consistently, previous studies have reported RKIP absence or downregulation and its clinical significance in a variety of human cancers, such as prostate, breast and gastric cancers (12-14). These observations led to intensive studies on 
the mechanisms and functions of RKIP in cancers; however, few previous studies have analyzed the RKIP methylation and expression status in ESCC. Using immunohistochemical analysis, Kim et al demonstrated that $71.4 \%$ of ESCC metastatic lymph nodes, $50.0 \%$ of primary ESCC and $28.9 \%$ of carcinoma in situ showed the loss of RKIP expression, suggesting that RKIP plays an inhibitory role in the invasion and metastasis of ESCC (15). In addition, Gao et al reported that positive expression of RKIP in ESCC occurred significantly less often than in paratumor normal tissues, and that reduced RKIP expression was significantly correlated with a higher risk of recurrence, implying its importance in prognosis prediction (16). Furthermore, the expression level of RKIP was decreased in the order of dysplastic Barrett's mucosa, low-grade dysplasia, high-grade dysplasia and EAC, suggesting its involvement in esophageal carcinogenesis (17).

Although these studies all support the significance of RKIP in ESCC, minimal information is known regarding the mechanisms leading to RKIP silencing in ESCC. Considering that promoter hypermethylation is an important mechanism for gene silencing, and that it plays an important role in downregulating RKIP in gastric carcinoma $(18,19)$, the authors of the present study hypothesized that promoter methylation may be a potential mechanism for downregulating RKIP in ESCC and is thus responsible for the biological behaviors of ESCC. To test this hypothesis, the RKIP promoter methylation status and its expression level in ESCC tissues and matched paratumor normal tissues were examined using methylation-specific polymerase chain reaction (MSP) and immunohistochemical staining, respectively. Furthermore, their correlations with distinct clinicopathological features of the patients were analyzed.

\section{Materials and methods}

Patients and tissue samples. The present study was approved by the Ethics Committee of Hebei Medical University (Shijiazhuang, China), where all data were collected, and written informed consent was obtained from all participants. A total of 77 patients (59 males and 18 females; mean age of $61.8 \pm 8.7$ years) who underwent radical surgery of ESCC in the Fourth Hospital of Hebei Medical University between December 2008 and December 2010 were recruited to this study. No patients received pre-operative chemotherapy or radiotherapy. Among these patients, 29 were aged $<60$ years, while 49 were aged $>60$ years. According to the tumor, lymph node, metastasis (TNM) staging criteria from the Union for International Cancer Control and the American Joint Committee on Cancer (20), 33 cases were of stage I or II and 44 cases were of stage III or IV. According to the pathological grading system (21), 20 ESCC cases were well-differentiated, 26 were moderately-differentiated, and 31 were poorly-differentiated cancers. Among these ESCC cases, 45 showed positive lymph node metastasis, while 32 showed negative lymph node metastasis. The clinicopathological characteristics of the patients are summarized in Table I.

During surgery, the cancer tissues and the matched normal tissues were obtained from the primary tumors and at least 5-cm away from the tumor, respectively. All tissues were immediately stored at $-80^{\circ} \mathrm{C}$, with some subsequently used for DNA extraction and some fixed in $10 \%$ formalin
Table I. Clinicopathological characteristics of esophageal squamous cell carcinoma cases in this study.

\begin{tabular}{lcc}
\hline Characteristic & $\mathrm{n}$ & $\%$ \\
\hline Gender & & \\
$\quad$ Male & 59 & 76.62 \\
Female & 18 & 23.38 \\
TNM stage & & \\
I + II & 33 & 42.86 \\
III+ IV & 44 & 57.14 \\
Pathological differentiation & & \\
Well & 20 & 25.97 \\
Moderate & 26 & 33.77 \\
Poor & 31 & 40.26 \\
Age (years) & & \\
$\quad<60$ & 29 & 37.66 \\
$\geq 60$ & 48 & 62.34 \\
Lymph node metastasis & & \\
$\quad$ Negative & 32 & 57.86 \\
Positive & 45 & \\
\hline
\end{tabular}

TNM, tumor-node-metastasis.

and embedded in paraffin for immunohistochemical staining. All matched normal tissues were confirmed by pathological examination to contain no invaded tumor cells.

Modified MSP method. Tissue samples were treated with proteinase $\mathrm{K}$, and genomic DNA was extracted using phenol/chloroform. Using the TU-1800 PC UV-VIS spectrophotometer (Beijing, China) to measure the absorbance ratio at $260 / 280 \mathrm{~nm}$, the total DNA purity was determined to be between 1.8 and 2.0. Bisulfite modification of $10 \mu \mathrm{g}$ genomic DNA from each sample was performed as described previously (22). Briefly, genomic DNA was denatured using $2 \mathrm{M} \mathrm{NaOH}$ and then incubated with $10 \mathrm{M}$ hydroquinone (Merck Millipore, Darmstadt, Germany) and $3 \mathrm{M}$ sodium bisulfite at $50^{\circ} \mathrm{C}$ for $16 \mathrm{~h}$. Modified DNA was purified using the Wizard DNA purification resin (Promega Corporation, Madison, WI, USA), according to the manufacturer's protocol. The MSP was performed using primers (Table II) under the following conditions: Predenaturation at $95^{\circ} \mathrm{C}$ for $12 \mathrm{~min} ; 36$ cycles at $95^{\circ} \mathrm{C}$ for $60 \mathrm{sec}, 52^{\circ} \mathrm{C}$ for $45 \mathrm{sec}$ and $72^{\circ} \mathrm{C}$ for $60 \mathrm{sec}$; and a final extension at $72^{\circ} \mathrm{C}$ for $10 \mathrm{~min}$. The polymerase chain reaction (PCR) products were subsequently separated on $2 \%$ agarose gels by electrophoresis and analyzed using an ultraviolet light gel imaging system (FOTODYNE Incorporated, Hartland, WI, USA). The peripheral blood from a healthy individual without any diseases or tumors in the alimentary system was taken to isolate genomic DNA, which, following methylation treatment using DNA methyltransferase (Sss I; Beijing Solarbio Science \& Technology, Co., Ltd., Beijing, China) was used as a positive control; that without Sss I treatment was used as a negative control. A water blank was also used as a negative control. The tissue samples showing positive PCR products only with methylated primers (full methylation) or with 
Table II. Sequences, Tm and amplicon sizes of primers used for RKIP methylation-specific PCR.

\begin{tabular}{llcc}
\hline & \multicolumn{1}{c}{ Primer sequences, $5^{\prime}-3^{\prime}$} & $\mathrm{Tm},{ }^{\circ} \mathrm{C}$ & PCR product size, bp \\
\hline $\mathrm{M}$ & $\begin{array}{l}\text { F TTTAGCGATATTTTTTGAGATACGA } \\
\text { R GCTCCCTAACCTCTAATTAACCG }\end{array}$ & 52.5 & 205 \\
$\mathrm{U}$ & $\begin{array}{l}\text { F TTTAGTGATATTTTTTGAGATATGA } \\
\text { R CACTCCCTAACCTCTAATTAACCAA }\end{array}$ & 52.5 & 205 \\
\hline
\end{tabular}

M, methylated RKIP; U, unmethylated RKIP; Tm, melting temperature; F, forward; R, reverse; RKIP, Raf kinase inhibitory protein.

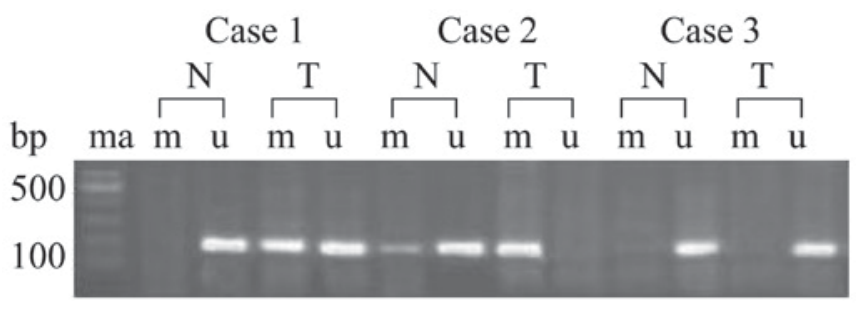

Figure 1. MSP analysis of RKIP promoter methylation in three representative ESCC tissues (T) and the matched paratumor normal tissues (N). The letters $\mathrm{m}$ and $\mathrm{u}$ indicate that the primers for methylated and unmethylated RKIP were used, respectively. RKIP, Raf kinase inhibitory protein.

both methylated and unmethylated primers (semi-methylation) were defined as methylated samples (23).

Immunohistochemical staining. Immunohistochemical staining for RKIP was performed on $4-\mu \mathrm{m}$ formalin-fixed, paraffin-embedded tissue sections using the Immunohistochemical Streptavidin-Peroxidasekit(ZSGB-BIO, Beijing, China), according to the manufacturer's protocol. Briefly, the tissue sections were dewaxed, dehydrated and treated with $3 \%$ hydrogen peroxidase to block endogenous peroxidase activity. Following antigen retrieval in EDTA solution ( $\mathrm{pH}$ 8.5) in a pressure cooker for $3 \mathrm{~min}$, the sections were blocked with $10 \%$ normal goat serum at $37^{\circ} \mathrm{C}$ for $40 \mathrm{~min}$, followed by incubation with the primary rabbit anti-human RKIP antibody (catalog no., bs-1436R; dilution, 1:500; Bioss, Beijing, China) and then horseradish peroxidase-labeled streptavidin. Final color development was achieved using a 3,3'-diaminobenzidine solution, and the slides were counterstained with $1 \%$ Meyer's hematoxylin. The use of phosphate-buffered saline instead of the primary antibody served as a negative control.

Positive RKIP staining appeared as yellowish to brownish granules in the cytoplasm. The staining was scored and averaged by three independent clinical pathologists according to a scoring system modified from that proposed by Fromowitz et al (24). Briefly, five random fields were imaged from each slide under a BX41 light microscope (Olympus, Tokyo, Japan). A score was assigned based on the percentage of positive tumor cells averaged from all five fields: Score 0, $\leq 25 \%$; score 1, 26-50\%; score 2, 51-75\%; and score 3, $>75 \%$. In addition, the staining was graded based on the intensity of the majority of the positively stained cells: 0 , no staining; 1 , weak yellowish staining; 2 , moderate brownish staining; and 3 , dark brownish staining. The final score was obtained by adding the percentage score and intensity grade, and stratified as: '-' $=0$; ' + ' $=1-2$; ' $++'=3-4$; and ' $+++'=5-6$, where ' - ' and ' + ' were classified as negative expression, while ' ++ ' and ' +++ ' were classified as positive expression.

Statistical analysis. All statistical analyses were performed using SPSS software version 13.0 (SPSS, Inc., Chicago, IL, USA). Quantitative data are presented as a percentage or ratio of the total sample. The association between groups was assessed using the $\chi^{2}$ test. $\mathrm{P}<0.05$ was considered to indicate a statistically significant difference.

\section{Results}

RKIP promoter methylation and protein expression in ESCC and paratumor normal tissues. To examine the status of RKIP promoter methylation in ESCC, MSP analysis on 77 ESCC tumor tissues and matched paratumor normal tissues was performed (Fig. 1). The incidence of RKIP promoter methylation in ESCC tissues was $75.3 \%$, which was significantly higher compared with the matched normal tissues (27.3\%; $\mathrm{P}<0.001$; Table III). Given that methylation-induced gene silencing is an important mechanism for downregulating many tumor suppressor genes during cancer development $(25,26)$, the expression level of RKIP in ESCC and normal tissues was also profiled by immunohistochemistry (Fig. 2). The incidence of positive RKIP expression in the ESCC tissues was 36.4\%, which was significantly reduced compared with the matched normal tissues (76.6\%; $\mathrm{P}<0.001$; Table III).

Correlation between RKIP promoter methylation and the clinicopathological characteristics of ESCC. The correlation between RKIP promoter methylation in ESCC and various clinicopathological characteristics is shown in Table IV. The incidence of RKIP promoter methylation was not significantly correlated with the age $(\mathrm{P}=0.528)$, gender $(\mathrm{P}=1.000)$ or TNM stage $(\mathrm{P}=0.321)$, although it was significantly correlated with the differentiation status of the tumor $(50.0 \%$ in well-differentiated tumors, $73.1 \%$ in moderately-differentiated tumors and $93.5 \%$ in poorly differentiated tumors; $\mathrm{P}=0.002$ ), as well as the lymph node status (86.7 and 59.4\% in ESCC patients with and without positive lymph node metastasis, respectively; $\mathrm{P}=0.006$ ).

Correlation between RKIP protein expression and the clinicopathological characteristics of ESCC. The analysis of the correlation between the incidence of RKIP protein expression in ESCC and various clinicopathological characteristics showed that the expression of RKIP in the tumor tissues was 
Table III. Methylation status and protein expression of RKIP in 77 ESCC tissues and the matched paratumor normal tissues.

\begin{tabular}{lcccc}
\hline & \multicolumn{2}{c}{ RKIP promoter methylation } & \multicolumn{2}{c}{ RKIP protein expression } \\
\cline { 2 - 4 } Tissues & Methylation & No methylation & Positive & Negative \\
\hline ESCC $(\mathrm{n}=77)$ & $58(75.32 \%)$ & $19(24.67 \%)$ & $28(36.36 \%)$ & $49(63.64 \%)$ \\
Normal $(\mathrm{n}=77)$ & $21(27.27 \%)$ & $54(72.73 \%)$ & $59(76.62 \%)$ & $18(23.38 \%)$ \\
$\chi^{2}$ & & 35.582 & & 25.389 \\
P-value & & $\mathrm{P}<0.001$ & & $\mathrm{P}<0.001$ \\
\hline
\end{tabular}

RKIP, Raf kinase inhibitory protein; ESCC, esophageal squamous cell carcinoma.

Table IV. Correlation between RKIP promoter methylation and the clinicopathological characteristics.

\begin{tabular}{|c|c|c|c|c|c|}
\hline \multirow[b]{2}{*}{ Characteristic } & \multicolumn{3}{|c|}{ RKIP promoter methylation } & \multirow[b]{2}{*}{$\chi^{2}$} & \multirow[b]{2}{*}{ P-value } \\
\hline & $\mathrm{n}$ & $\mathrm{M}$ & $\mathrm{U}$ & & \\
\hline Age (years) & & & & & 0.528 \\
\hline$<60$ & 29 & 23 & 6 & 0.398 & \\
\hline$\geq 60$ & 48 & 35 & 13 & & \\
\hline Gender & & & & & 1.000 \\
\hline Male & 59 & 44 & 15 & 0.076 & \\
\hline Female & 18 & 14 & 4 & & \\
\hline Clinical stage & & & & & 0.321 \\
\hline $\mathrm{I}+\mathrm{II}$ & 33 & 23 & 10 & 0.984 & \\
\hline III+IV & 44 & 35 & 9 & & \\
\hline Degree of differentiation & & & & & 0.002 \\
\hline Well & 20 & 10 & 10 & 12.511 & \\
\hline Moderate & 26 & 19 & 7 & & \\
\hline Poor & 31 & 29 & 2 & & \\
\hline Lymph node metastasis & & & & & 0.006 \\
\hline Negative & 32 & 19 & 13 & 7.494 & \\
\hline Positive & 45 & 39 & 6 & & \\
\hline
\end{tabular}

M, methylated RKIP; U, unmethylated RKIP; RKIP, Raf kinase inhibitory protein.
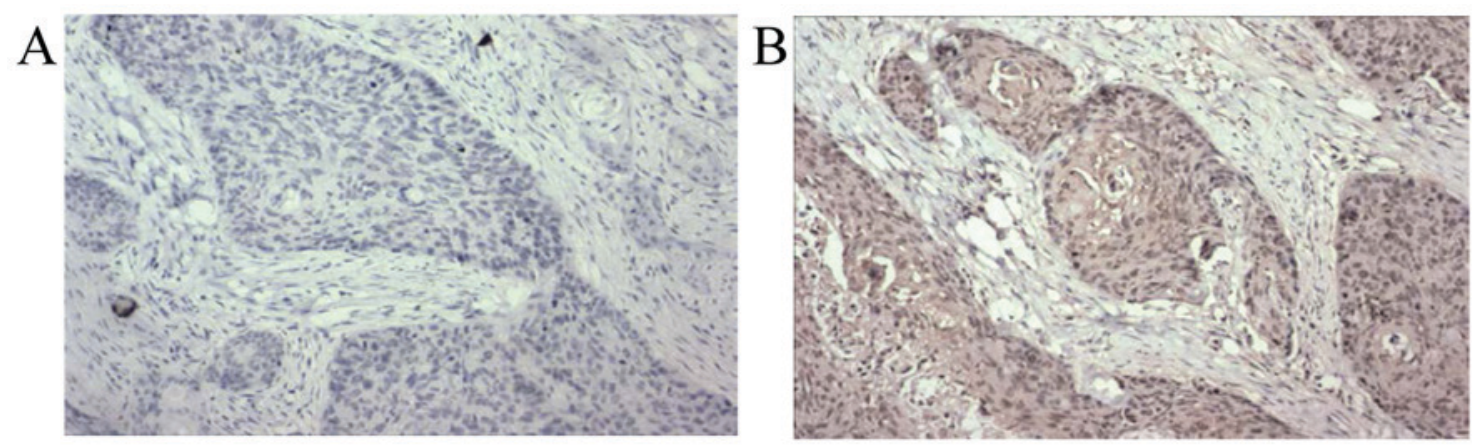

Figure 2. Immunohistochemical staining of Raf kinase inhibitory protein (brown signals) in (A) a representative ESCC tissue and (B) the matched paratumor normal tissue (magnification, x200).

only significantly correlated with lymph node metastasis (24.4 and 53.1\% in ESCC patients with and without positive lymph node metastasis, respectively; $\mathrm{P}=0.01)$; it was not significantly associated with age $(\mathrm{P}=0.540)$, gender $(\mathrm{P}=0.760)$, 
Table V. Correlation between RKIP protein expression and clinicopathological characteristics.

\begin{tabular}{|c|c|c|c|c|c|}
\hline \multirow[b]{2}{*}{ Characteristic } & \multirow[b]{2}{*}{$\mathrm{n}$} & \multicolumn{2}{|c|}{ RKIP protein expression } & \multirow[b]{2}{*}{$\chi^{2}$} & \multirow[b]{2}{*}{ P-value } \\
\hline & & Positive & Negative & & \\
\hline Age, years & & & & 0.571 & 0.450 \\
\hline$<60$ & 29 & 9 & 20 & & \\
\hline$\geq 60$ & 48 & 19 & 29 & & \\
\hline Gender & & & & 0.093 & 0.760 \\
\hline Male & 59 & 22 & 37 & & \\
\hline Female & 18 & 6 & 12 & & \\
\hline Clinical stage & & & & 3.667 & 0.056 \\
\hline $\mathrm{I}+\mathrm{II}$ & 33 & 16 & 17 & & \\
\hline III + IV & 44 & 12 & 32 & & \\
\hline Degree of differentiation & & & & 2.535 & 0.282 \\
\hline Well & 20 & 9 & 11 & & \\
\hline Moderate & 26 & 11 & 15 & & \\
\hline Poor & 31 & 8 & 23 & & \\
\hline Lymph node metastasis & & & & 6.648 & 0.010 \\
\hline Negative & 32 & 17 & 15 & & \\
\hline Positive & 45 & 11 & 34 & & \\
\hline
\end{tabular}

RKIP, Raf kinase inhibitory protein.

Table VI. Association between RKIP promoter methylation and protein expression in esophageal squamous cell carcinoma tissues.

\begin{tabular}{lrrrrr}
\hline & \multicolumn{2}{c}{$\begin{array}{c}\text { RKIP } \\
\text { protein expression }\end{array}$} & & & \\
\cline { 2 - 5 } RKIP methylation status & + & - & Total & $\chi^{2}$ & 17.308 \\
\hline Methylated & 17 & 41 & 58 & 0.001 \\
Unmethylated & 11 & 8 & 19 & \\
Total & 28 & 49 & 77 & \\
\hline
\end{tabular}

RKIP, Raf kinase inhibitory protein.

TNM stage $(\mathrm{P}=0.056)$ or the differentiation status of the tumor $(\mathrm{P}=0.282$; Table $\mathrm{V})$.

Association between RKIP promoter methylation and protein expression. Among the $58 \mathrm{ESCC}$ tissues positive for RKIP promoter methylation, $29.3 \%$ were positive for RKIP protein expression. Of the $19 \mathrm{ESCC}$ tissues negative for RKIP promoter methylation, $57.9 \%$ were positive for RKIP protein expression. There was a significant negative association between RKIP promoter methylation and protein expression $(\mathrm{P}=0.001$; Table VI).

\section{Discussion}

The present study examined the status of RKIP promoter methylation and its expression in ESCC and matched paratumor normal tissues, and demonstrated that RKIP promoter methylation was significantly enhanced, while its protein expression level was significantly reduced, in the tumor tissues compared with the normal tissues. Functionally, RKIP promoter methylation was significantly correlated with the status of tumor differentiation and lymph node metastasis, while RKIP protein expression was associated with lymph node metastasis only. Consistent with these observations, RKIP promoter methylation was negatively associated with its protein expression in ESCC tissues.

Tumorigenesis is a complicated process involving numerous factors, multiple steps and genetic as well as epigenetic alterations in various genes. The pathogenesis of ESCC has been mainly attributed to environmental factors, including malnutrition, smoking, alcohol use and inflammation (27-29). However, recent studies have revealed that genetic and 
epigenetic alterations also play significant roles in the development of multiple cancers, including ESCC (30-32). Among various epigenetic alterations, aberrant DNA methylation (including hypomethylation of oncogenes and hypermethylation of tumor suppressor genes) is the best characterized and most crucial mechanism modulating chromatin structure and the expression levels of oncogenes or tumor suppressor genes, contributing to tumor initiation and further development (33). Hypermethylation of the $\mathrm{CpG}$ islands within the promoter regions of tumor suppressor genes is a well-demonstrated molecular mechanism for transcriptional silencing and subsequent tumor progression (34). The presence of promoter $\mathrm{CpG}$ island hypermethylation in preneoplastic lesions of malignant cancers supports its significance in neoplastic transformation and tumor initiation (35-38).

Many studies have corroborated the nature of RKIP as a tumor suppressor gene. Li et al reported that promoter hypermethylation of the RKIP gene led to its silencing in colorectal cancer, which may underlie tumor metastasis (39). Al-Mulla et al demonstrated that chromosome loss in colorectal cancer was inversely proportional to RKIP expression levels, the silencing of which was mainly caused by methylation of the RKIP promoter (40). Consistently, other studies have supported the importance of RKIP promoter hypermethylation in the loss of its activity $(41,42)$. In contrast, few studies have investigated the status or clinical significance of RKIP promoter methylation in ESCC. To address this issue, the present study compared promoter methylation of the RKIP gene in ESCC tissues and the matched normal tissues of 77 patients with ESCC, and showed that RKIP promoter hypermethylation was significantly enhanced in the tumor tissues compared with the normal tissues, supporting its potential involvement in tumor initiation. Furthermore, RKIP promoter hypermethylation was significantly correlated with tumor differentiation and lymph node metastasis, suggesting its value in predicting ESCC metastasis and prognosis.

In the paratumor normal tissues, $27.3 \%$ were positive for RKIP promoter methylation, and all these cases were semi-methylated (data not shown). One potential explanation for this was that we used the highly sensitive nested MSP for this study, which is capable of detecting alleles comprising $<5 \%$ of the total genomic DNA (43). Therefore, minor invasion of the tumor tissue into the normal tissue (although negative in the pathological examinations) may have led to semi-methylation. Among the 58 ESCC samples positive for RKIP promoter methylation, 3 were semi-methylated (data not shown), which may be related to the degree of transcriptional silencing of RKIP; that is, an incomplete methylation corresponds to incomplete gene silencing (44).

In addition to promoter methylation, reduced or loss of RKIP expression has been associated with cancer development. Immunohistochemical analysis has demonstrated that the loss of RKIP expression is a key phenotype for many human cancers, including colorectal cancer, breast cancer, melanoma, prostate cancer and hepatocellular carcinoma, modulating distant metastasis, lymphatic metastasis, vascular infiltration and cancer mortality (45-49). Consistent with these studies, the present study showed that the incidence of positive RKIP expression in ESCC tissues was significantly less compared with the matched normal tissues, and that it was clinically correlated with lymph node metastasis. A further association analysis revealed that promoter methylation-induced RKIP silencing may be a major mechanism for downregulating RKIP and subsequent ESCC development.

The potential involvement of RKIP as a tumor suppressor gene in tumor invasiveness and metastasis has been well demonstrated in multiple cancers. Keller et al reported that RKIP expression was at its highest in normal prostate tissues, decreased in primary prostate cancers and was not detectable in metastatic tissues from prostate cancer (50). In addition, Schuierer et al demonstrated that RKIP expression was decreased concomitantly with the metastasis of melanoma (47). Mechanistic studies have suggested that RKIP is a metastasis suppressor gene that is responsible for blocking several signaling pathways in the metastatic cascade, including MEK, G proteins and NF- $\mathrm{KB}$ (51). Similarly, the present study showed that the percentage of RKIP expression in ESCC tumors with lymph node metastasis was significantly less compared with tumors without lymph node metastasis.

In summary, this study showed that promoter methylation may be responsible for RKIP downregulation and the oncogenesis of ESCC. Therefore, the incidence of RKIP promoter methylation may serve as a biomarker for the differentiation status and prognosis of ESCC. This study extends the molecular understanding of the pathogenesis of ESCC and provides a novel target for the early diagnosis and treatment of ESCC.

\section{Acknowledgements}

This study was supported by the Research Project of Science and Technology of Handan (grant no. 1123108079-4).

\section{References}

1. Chen W, Zheng R, Zeng H, Zhang S and He J: Annual report on status of cancer in China, 2011. Chin J Cancer Res 27: 2-12, 2015.

2. Li H: Modern esophageal surgery. People's Military Medical Press, Beijing, pp331-332, 2004.

3. Esophageal cancer: Epidemiology, pathogenesis and prevention. Nat Clin Pract Gastroenterol Hepatol 5: 517-526, 2008.

4. Holmes RS and Vaughan TL: Epidemiology and pathogenesis of esophageal cancer. Semin Radiat Oncol 17: 2-9, 2007.

5. Li JS, Ying JM, Wang XW, Wang ZH, Tao Q and Li LL: Promoter methylation of tumor suppressor genes in esophageal squamous cell carcinoma. Chin J Cancer 32: 3-11, 2013.

6. Cheng CP, Kuo IY, Alakus H, Frazer KA, Harismendy O, Wang YC and Tseng VS: Network-based analysis identifies epigenetic biomarkers of esophageal squamous cell carcinoma progression. Bioinformatics 30: 3054-3061, 2014.

7. Bernier I and Jollés P: Purification and characterization of a basic $23 \mathrm{kDa}$ cytosolic protein from bovine brain. Biochim Biophys Acta 790: 174-181, 1984.

8. Yeung K, Seitz T, Li S, Janosch P, McFerran B, Kaiser C, Fee F, Katsanakis KD, Rose DW, Mischak H, et al: Suppression of Raf-1 kinase activity and MAP kinase signalling by RKIP. Nature 401: 173-177, 1999.

9. Yeung KC, Rose DW, Dhillon AS, Yaros D, Gustafsson M, Chatterjee D, McFerran B, Wyche J, Kolch W and Sedivy JM: Raf kinase inhibitor protein interacts with NF-kappaB-inducing kinase and TAK1 and inhibits NF-kappaB activation. Mol Cell Biol 21: 7207-7217, 2001.

10. Deiss K, Kisker C, Lohse MJ and Lorenz K: Raf kinase inhibitor protein (RKIP) dimer formation controls its target switch from Raf1 to G protein-coupled receptor kinase (GRK) 2. J Biol Chem 287: 23407-23417, 2012.

11. Escara-Wilke J, Yeung K and Keller ET: Raf kinase inhibitor protein (RKIP) in cancer. Cancer Metastasis Rev 31: 615-620, 2012. 
12. Fu Z, Smith PC, Zhang L, Rubin MA, Dunn RL, Yao Z and Keller ET: Effects of raf kinase inhibitor protein expression on suppression of prostate cancer metastasis. J Natl Cancer Inst 95: 878-889, 2003

13. Zhao Z, Lu P, Zhang H, Xu H, Gao N, Li M and Liu C: Nestin positively regulates the $\mathrm{Wnt} / \beta$-catenin pathway and the proliferation, survival and invasiveness of breast cancer stem cells. Breast Cancer Res 16: 408, 2014.

14. Liu C, Lu P, Lu Y, Xu H, Wang S and Chen J: Clinical implications of metastatic lymph node ratio in gastric cancer. BMC Cancer 7: 200, 2007.

15. Kim HS, Won KY, Kim GY, Kim SC, Park YK and Kim YW: Reduced expression of Raf-1 kinase inhibitory protein predicts regional lymph node metastasis and shorter survival in esophageal squamous cell carcinoma. Pathol Res Pract 208: 292-299, 2012.

16. Gao C, Pang L, Ren C and Ma T: Prognostic value of raf kinase inhibitor protein in esophageal squamous cell carcinoma. Pathol Oncol Res 18: 471-477, 2012.

17. Birner P, Jesch B, Schultheis A and Schoppmann SF: RAF-kinase inhibitor protein (RKIP) downregulation in esophageal cancer and its metastases. Clin Exp Metastasis 29: 551-559, 2012.

18. Guo W, Dong Z, Guo Y, Lin X, Chen Z, Kuang G and Yang Z: Aberrant methylation and loss expression of RKIP is associated with tumor progression and poor prognosis in gastric cardia adenocarcinoma. Clin Exp Metastasis 30: 265-275, 2013.

19. Li DX, Cai HY, Wang X, Feng YL and Cai SW: Promoter methylation of Raf kinase inhibitory protein: A significant prognostic indicator for patients with gastric adenocarcinoma. Exp Ther Med 8: 844-850, 2014.

20. Edge SB and Compton CC: The American Joint Committee on Cancer: The 7th edition of the AJCC cancer staging manual and the future of TNM. Ann Surg Oncol 17: 1471-1474, 2010.

21. Rice TW, Blackstone EH and Rusch VW: 7th edition of the AJCC Cancer Staging Manual: Esophagus and esophagogastric junction. Ann Surg Oncol 17: 1721-1724, 2010

22. Herman JG, Graff JR, Myöhänen S, Nelkin BD and Baylin SB: Methylation-specific PCR: A novel PCR assay for methylation status of CpG islands. Proc Natl Acad Sci USA 93: 9821-9826, 1996.

23. Glickman JF, Flynn J and Reich NO: Purification and characterization of recombinant baculovirus-expressed mouse DNA methyltransferase. Biochem Biophys Res Commun 230: 280-284, 1997.

24. Fromowitz FB, Viola MV, Chao S, Oravez S, Mishriki Y, Finkel G, Grimson R and Lundy J: ras p21 expression in the progression of breast cancer. Hum Pathol 18: 1268-1275, 1987.

25. Baylin SB: DNA methylation and gene silencing in cancer. Nat Clin Pract Oncol 2 (Suppl 1): S4-S11, 2005.

26. Kulis M and Esteller M: DNA methylation and cancer. Adv Genet 70: 27-56, 2010.

27. Yang CS: Vitamin nutrition and gastroesophageal cancer. J Nutr 130 (Suppl 2S): S338-S339, 2000.

28. Yokokawa Y, Ohta S, Hou J, Zhang XL, Li SS, Ping YM and Nakajima T: Ecological study on the risks of esophageal cancer in Ci-Xian, China: The importance of nutritional status and the use of well water. Int J Cancer 83: 620-624, 1999.

29. Launoy G, Milan CH, Faivre J, Pienkowski P, Milan CI and Gignoux M: Alcohol, tobacco and oesophageal cancer: Effects of the duration of consumption, mean intake and current and former consumption. Br J Cancer 75: 1389-1396, 1997.

30. Gao YB, Chen ZL, Li JG, Hu XD, Shi XJ, Sun ZM, Zhang F, Zhao ZR, Li ZT, Liu ZY, et al: Genetic landscape of esophageal squamous cell carcinoma. Nat Genet 46: 1097-1102, 2014.

31. Sasaki Y, Tamura M, Koyama R, Nakagaki T, Adachi Y and Tokino T: Genomic characterization of esophageal squamous cell carcinoma: Insights from next-generation sequencing. World J Gastroenterol 22: 2284-2293, 2016.
32. Kailasam A, Mittal SK and Agrawal DK: Epigenetics in the pathogenesis of esophageal adenocarcinoma. Clin Transl Sci 8: 394-402, 2015.

33. Ma K, Cao B and Guo M: The detective, prognostic, and predictive value of DNA methylation in human esophageal squamous cell carcinoma. Clin Epigenetics 8: 43, 2016.

34. Shames DS, Minna JD and Gazdar AF: DNA methylation in health, disease, and cancer. Curr Mol Med 7: 85-102, 2007.

35. Jones PA, Rideout WM III, Shen JC, Spruck CH and Tsai YC: Methylation, mutation and cancer. Bioessays 14: 33-36, 1992.

36. Pogribny I, Raiche J, Slovack $M$ and Kovalchuk O: Dose-dependence, sex- and tissue-specificity, and persistence of radiation-induced genomic DNA methylation changes. Biochem Biophys Res Commun 320: 1253-1261, 2004

37. Brooks JD, Weinstein M, Lin X, Sun Y, Pin SS, Bova GS Epstein JI, Isaacs WB and Nelson WG: CG island methylation changes near the GSTP1 gene in prostatic intraepithelial neoplasia. Cancer Epidemiol Biomarkers Prev 7: 531-536, 1998.

38. Chan $\mathrm{AO}$ and Rashid $\mathrm{A}: \mathrm{CpG}$ island methylation in precursors of gastrointestinal malignancies. Curr Mol Med 6: 401-408, 2006.

39. Li FF, Song SJ and Zhang RN: Phosphatidylethanolamine-binding protein (PEBP) in basic and clinical study. Sheng Li Ke Xue Jin Zhan 40: 214-218, 2009 (In Chinese).

40. Al-Mulla F, Hagan S, Al-Ali W, Jacob SP, Behbehani AI, Bitar MS, Dallol A and Kolch W: Raf kinase inhibitor protein: Mechanism of loss of expression and association with genomic instability. J Clin Pathol 61: 524-529, 2008.

41. Eves EM, Shapiro P, Naik K, Klein UR, Trakul N and Rosner MR: Raf kinase inhibitory protein regulates aurora B kinase and the spindle checkpoint. Mol Cell 23: 561-574, 2006.

42. Martinho O, Gouveia A, Silva P, Pimenta A, Reis RM and Lopes JM: Loss of RKIP expression is associated with poor survival in GISTs. Virchows Arch 455: 277-284, 2009.

43. Licchesi JD and Herman JG: Methylation-specific PCR. Methods Mol Biol 507: 305-323, 2009.

44. Bird A: Molecular biology. Methylation talk between histones and DNA. Science 294: 2113-2115, 2001.

45. Minoo P, Zlobec I, Baker K, Tornillo L, Terracciano L, Jass JR and Lugli A: Loss of raf-1 kinase inhibitor protein expression is associated with tumor progression and metastasis in colorectal cancer. Am J Clin Pathol 127: 820-827, 2007.

46. Hagan S, Al-Mulla F, Mallon E, Oien K, Ferrier R, Gusterson B, García JJ and Kolch W: Reduction of Raf-1 kinase inhibitor protein expression correlates with breast cancer metastasis. Clin Cancer Res 11: 7392-7397, 2005.

47. Schuierer MM, Bataille F, Hagan S, Kolch W and Bosserhoff AK: Reduction in Raf kinase inhibitor protein expression is associated with increased Ras-extracellular signal-regulated kinase signaling in melanoma cell lines. Cancer Res 64: 5186-5192, 2004.

48. Fu Z, Kitagawa Y, Shen R, Shah R, Mehra R, Rhodes D, Keller PJ, Mizokami A, Dunn R, Chinnaiyan AM, et al: Metastasis suppressor gene Raf kinase inhibitor protein (RKIP) is a novel prognostic marker in prostate cancer. Prostate 66: 248-256, 2006

49. Schuierer MM, Bataille F, Weiss TS, Hellerbrand C and Bosserhoff AK: Raf kinase inhibitor protein is downregulated in hepatocellular carcinoma. Oncol Rep 16: 451-456, 2006.

50. Keller ET, Fu Z, Yeung K and Brennan M: Raf kinase inhibitor protein: A prostate cancer metastasis suppressor gene. Cancer Lett 207: 131-137, 2004.

51. Keller ET: Metastasis suppressor genes: A role for raf kinase inhibitor protein (RKIP). Anticancer Drugs 15: 663-669, 2004. 